By GEORGE B. BROWN

\title{
In-Service Training in Acquisition Work
}

Mr. Brown is chief of the Acquisition Department, University of Illinois Library.

$\mathrm{F}^{\mathrm{OR}}$ THE past two years an in-service $\Gamma_{\text {training program has been in progress }}$ in the Acquisition Department of the University of Illinois Library. It has been conducted on an experimental basis and it is believed that a report of the organization and teaching of the course and its content might be of interest to other members of the profession.

In a recent article on this subject, E. A. Wight ${ }^{1}$ quotes Tucker's definition of inservice training as "management's process of aiding employees to gain effectiveness in their present and future work assignments by providing, planning and organizing a program of systematic instruction and practice on the job." This definition seems fairly adequate for our purposes.

In Wight's summary he states that "given reasonably adequate general and professional education, a stimulating professional job with adequate pay, working and living conditions that promote high morale, and access to types of intellectual stimulation that are common in good colleges, the professional librarian will continue professional growth without the necessity of a systematic program of in-service training."

Rudolf $\mathrm{Hirsch},{ }^{2}$ in an article on the in-

1 Wight, Edward A. "In-Service Training of Professional Libraries in College and Universities Libraries." College and Research Libraries, 10:103-07, April

${ }_{2}^{19}$ Hirsch, Rudolf. "The In-Service Training Program of the University of Pennsylvania Library." College and Research Libraries, I0:108-12', April 1949. service training program at the University of Pennsylvania Library, describes the training in librarianship of selected students without previous library school education. He points out that this type of program puts a great burden on the instructional staff and that it is doubtful whether such a program could be made a regular function of the library. We would agree with $\mathrm{Mr}$. Hirsch's conclusions, although being somewhat envious of the rather thorough educational training the students apparently received, and would disagree with Dr. Wight's conclusions, particularly if applied to large university research libraries.

Our program was started after examination of proposed new curricula in library schools disclosed the fact that training in the technical aspects of library work and in the use of bibliographical tools were to receive considerably less attention than in the past. The new curricula in general seemed designed to reduce the amount of practical professional education in order to make room for more courses of a general nature designed to teach principles and theories rather than techniques. It necessarily follows that the techniques of the profession will have to be taught on the job after students have received their degrees, rather than in library school classes.

Those of us responsible for library administration recognize the need for a knowledge of techniques in addition to a knowledge of principles. The program at Illinois was developed and carried out only in the Acquisition Department and entirely 
by Acquisition Department personnel as an experiment and possible future guide for the establishment of similar programs in other departments of the library.

We have in mind training each staff member to handle the duties of his own position in the most efficient manner; familiarizing him with the importance of acquisition work and its place in relation to all other departments of the library; presenting some orientation in the work of all other members of the division in which the individual works in order that the various members of the division may be mutually helpful; and giving a fairly detailed knowledge of the operations of all other divisions of the department and operations of other departments of the library as they affect the Acquisition Department. In addition, any matter of general interest to the staff might become a subject of discussion in the class sessions. In essence, then, our program was designed to give each staff member the best possible training in the duties he was expected to perform, and to give him the whole picture of acquisition work as far as possible in order to prepare him for promotion within this library or to positions elsewhere.

The training was divided into two parts, each of approximately 12 weeks duration. The first 12 weeks consisted of strict "onthe-job" training; this was restricted to new staff members. Each new staff member was assigned to one of the more experienced bibliographers for training. This training consisted of day-to-day guidance in learning the bibliographical tools, procedures, and policies, and frequent conferences concerning special problems. The second 12 weeks was a more or less formal presentation for one hour per week, and the classes were open to the entire staff of the department.

The class sessions were designed as seminars with a lecture of roughly 40 minutes followed by a discussion of 20 minutes. In general, members of the staff showed a lively interest and several of the discussions lasted longer than the allotted period and would have continued if time had permitted.

As to the content of these class sessions, it should be explained that four of the I 2 sessions were conducted by the acquisition librarian as general sessions and eight were concerned with specific divisions of the department. In the first general session, the acquisition librarian outlined the purpose of the course and presented a discussion on the organization of the library and particularly of the Acquisition Department, general policies and procedures of the department, and a short summary of Farmington Plan operations. The second, third, and fourth sessions were presented by members of the Gift and Exchange Division, and Serials Section. The general organization of the Gift and Exchange Division was discussed along with some historical background concerning exchange practices among libraries, details of how exchanges are arranged, information concerning the procedures for handling gift and exchange materials, and the keeping of records. Other sessions covered the acquisition and processing of documents, general continuations, and special problems of serials. The fifth meeting was a general session in which, among others, the following items were discussed: Latest developments in the microcard publication program, new procedures in the Catalog Department which affect Acquisition Department records, new policy concerning disposition of odd numbers of periodicals, reports from the administrative staff conference of interest to Acquisition Department personnel, possibilities of closer coordination between bibliographers in the Acquisition Department and catalogers, new micro-offset 
processes for reprinting books, and the operations of the United States Book Exchange.

Naturally, subjects for discussion in these general sessions will vary from year to year, but in general they are designed to help members of the department keep up to date on all new policies, procedures, and other developments which might affect their work.

The sixth session was conducted by the head of the Periodical Division who discussed general organization of the division, methods of handling subscriptions, maintenance of records, and bibliographical peculiarities of periodicals.

The seventh session was conducted by the head of the Special Collections Division who explained its general organization, activities, and procedures. The eighth session was conducted by the head of the Purchase Division who discussed organization, the processing of orders, the use of bibliographical sources, records maintained in the division, selection of agents, and processing of books and invoices.

The ninth meeting was a general session and was devoted very largely to a discussion of what happens to books after they leave the Acquisition Department. It included the organization of the Catalog Department; routing slip procedures; the distribution of books to specialists in various subject fields for cataloging; problems dealing with serial cataloging and cataloging of other special types of material such as music, maps, dissertations and rare books; and delivery of the books to departmental libraries and other special locations.

The tenth session was devoted to a discussion of rare books and photographic reproductions. It was conducted by the consultant in bibliography in the Acquisition Department. The discussion included consideration of the various types of materials which automatically are sent to the rare book room; the definitions which determine whether a book is considered rare or not; some mention of faculty members and others especially active in selecting rare books; special procedures for searching and bibliographical verification of these publications; and special catalogs, bibliographies and procedures for processing the books when they are received. This latter procedure involves such matters as collation, comparison with other copies in the library, and forwarding information to the rare book librarian or to the Catalog Department about unusual sources of bibliographical verification. Some mention was also made of booksellers in the rare book field with their specialties and methods of operation.

Special procedures for handling orders for photographic reproductions were explained, and various printed lists and bibliographies of microfilms were displayed and described. Special conditions under which microfilms are furnished by various libraries were mentioned as were other procedures which vary from the routine processing of book orders.

The eleventh meeting was concerned with the business operations of the department. The session was presented by the acquisition librarian and included discussion of business forms, punched card equipment, accounting procedures, legal provisions in the university statutes which affect purchases, allocation of funds, processing of invoices, handling of statements, and writing of correspondence in relation to purchases.

The final session was designated as a general session at which all the members of the class participated in a critique of the year's program and discussed plans for continuing the classes in future years.

This rather detailed description of the course has been given in this paper in the hope that it may be useful to others planning 
similar programs. We believe that there is a sufficient content to acquisition work to justify an in-service training program to supplement library school courses and to make up for the omission of this type of education in the curriculum.

The classes were open to all members of the Acquisition Department, professional and clerical, but only the professional staff members were required to attend. Actually many of the clerks in the department did attend regularly and were able to make contributions to the discussions.

One of the benefits of this program has been a better understanding on the part of each staff member of the relationships between his work and the work of other members of the department and of the library staff. We are convinced that each staff member is now able to see his part in the total picture with greater clarity than was possible heretofore, and that there is a general feeling of satisfaction in sharing in this important work of building up research collections for a large university library. The boost in morale as a result of these sessions has been clearly noticeable. We believe it stems from an appreciation on the part of each staff member of being kept informed of the thinking and planning of the administrative staff, and of being given a chance to contribute his own thoughts and ideas for the improvement of the department as a whole.

It would be desirable to have some objective measurements as bases for evaluating the effectiveness of this training program; however, during its experimental years it did not lend itself to testing. We are now working on a method of testing which will help us decide whether such in-service training performs its declared functions and whether its cost is justifiable.

Our program will be continued next year, but directed more particularly to the needs of new staff members who will come to us immediately after graduation from library school. Staff members who have completed the in-service training will attend only the monthly general sessions. Other changes will be made as needs indicate; but in any case, in a very large research library, we are convinced that some such program is essential.

\section{Western Reserve Fellowship}

Western Reserve University School of Library Science will offer for the academic year I95I-52 eight half-tuition fellowships. Graduates of approved colleges who have a betterthan-usual academic record are encouraged to apply. These working programs should appeal to persons who desire to work closely with individual instructors in specific subject fields. A view of teaching methods and of collecting materials for instruction will be made available to the approved candidate. Service of the individual student will not exceed ro hours of work a week for one semester in return for a half-tuition credit throughout the year. The candidates who receive the awards will still be able to complete the work for the M.S. in L.S. degree with one basic year. Inquiries should be addressed to Thirza E. Grant, dean, School of Library Science, Western Reserve University, Cleveland 6, Ohio. 